\title{
Length-weight Relationship and Relative Condition Factor of Two Dominant Species (Cyclocheilithys apogon and Notopterus notopterus) at Subang Lake, Selangor, Malaysia
}

\section{Xeai Li Chai ${ }^{1}$, Rohasliney Hashim ${ }^{1 *}$, Muhammad Nur Aiman Rahmat ${ }^{1}$, Mohamad Hamizan Kamaludin ${ }^{1}$, Nur Ain Habullah ${ }^{1}$ and Izharuddin Shah Kamaruddin ${ }^{2}$}

${ }^{1}$ Department of Environment, Faculty of Forestry and Environment, Universiti Putra Malaysia, 43400 UPM, Serdang, Selangor Darul Ehsan, Malaysia

${ }^{2}$ Department of Aquaculture, Faculty of Agriculture, Universiti Putra Malaysia, 43400 UPM, Serdang, Selangor Darul Ehsan, Malaysia

\begin{abstract}
Length-weight relationships and relative condition factors were conducted to provide information on fish species' growth conditions and general well-being in the freshwater habitat. This study was conducted using fish as a bioindicator for the health of the ecosystem. Cyclocheilithys apogon (Beardless barb) and Notopterus notopterus (Bronze featherback) are the most dominant species in Subang Lake. A four-month sampling was conducted to collect the sample of Beardless barb and Bronze featherback. A total of 422 individuals of Beardless barb and 344 individuals of Bronze featherback were measured

ARTICLE INFO

Article history:

Received: 1 March 2021

Accepted: 19 April 2021

Published: 31 July 2021

DOI: https://doi.org/10.47836/pjst.29.3.44

E-mail addresses:

shailychai94@gmail.com (Xeai Li Chai)

rohasliney@upm.edu.my (Rohasliney Hashim)

muhammadnuraiman399@gmail.com (Muhammad Nur Aiman Rahmat)

mohamadhamizan1012@gmail.com (Mohamad Hamizan

Kamaludin)

nurain0496@yahoo.com (Nur Ain Habullah)

izharuddin@upm.edu.my (Izharuddin Shah Kamaruddin)

*Corresponding author and weighed. The mean total length of Breadless barb was $13.11 \pm 1.31 \mathrm{~cm}$ with the mean weight of $31.88 \pm 9.93 \mathrm{~g}$. The mean of the total length and weight of Bronze featherback was $16.05 \pm 2.07 \mathrm{~cm}$ and 30.38 $\pm 15.63 \mathrm{~g}$. Both fish species showed negative allometric growth with the exponent $b$ value 2.884 and 2.886 , respectively. The condition factor of Beardless barb (1.184 $\pm 0.134)$ and Bronze featherback (1.010 \pm 0.163 ) obtained from this study reflects a fair growth condition based on $\mathrm{K}$ value by
\end{abstract}


Xeai Li Chai, Rohasliney Hashim, Muhammad Nur Aiman Rahmat, Mohamad Hamizan Kamaludin,

Nur Ain Habullah and Izharuddin Shah KamaruddinUshada and David Yudianto

Barnham \& Baxter (2003). Further studies need to be conducted to determine the significant impacts that affect fish species' growth conditions.

Keywords: Freshwater fishes, length-weight relationship, relative condition factor, Subang lake

\section{INTRODUCTION}

The information such as the fish species' growth pattern, general health of fish, habitat conditions, and the fish's morphological characteristics can be revealed by the Lengthweight relationships (LWR) (Jisr et al., 2018; Froese, 2006). LWR is widely applied in fisheries management because it provides information on the stock condition and indicates the degree of stabilization of fish's taxonomic characters (Isa et al., 2010). There are several studies of the length-weight relationship and condition factor in Malaysia. According to Amonodin et al. (2018), there were approximately 102 LWR studies of 64 species that belong to 20 families. The Cyprinidae was the most studied family in the Malaysian freshwater system. Amonodin et al. (2018) documented a higher number of fish species experienced positive allometric growth, whereas a lower number of fish species experienced negative allometric growth in the Malaysian freshwater system. The variation of fish growth was attributed by the environmental condition, seasonal variation, general fish condition, age, maturity, health, and stomach fullness (Kaur \& Rawal, 2017). Fish species experienced positive allometric growth in a generally healthy environment with sufficient food supply and good water quality condition, whereas, fish species experienced negative allometric growth in a poor environmental condition. Also, the variation of fish growth was affected by the adaptive response of fish response to the ecological condition (Kaur \& Rawal, 2017).

Meanwhile, the condition factor is used to demonstrate the state of fish well-being and useful indicators of fish growth rate (Farooq et al., 2017). A fish's condition indicates the fish's current physical and biological circumstances; thus, the condition factor provides essential information about the present and future population success via its association with growth, reproduction, and survival. Apparently, in a favorable environmental condition, fish species should demonstrate faster growth rates, more significant reproductive potential, and higher survival rates (Pope, 2007). According to Karna et al. (2012), environmental condition is an important factor that induced the phenotypic flexibility. Also, most studies suggested that there is a significant relationship between temperature, population size, and the maturity of fish.

The Subang Lake is an undisturbed endorheic lake surrounded by hilly and forested area, and there is no study concerning the fish LWR and condition, especially on these native species (Beardless barb and Bronze featherback) found in the lake. Hence, this study's objective was to estimate the LWR of two dominant native species, Beardless barb and Bronze featherback, and determine the Kn that evaluates fish growth condition to further 
relate to the environment condition. Consequently, this knowledge is essential to local management to prioritize the control and coordination fisheries' management options for native species in Subang Lake. This study demonstrates the understanding of these native species' growth and their condition in a small and undisturbed water body.

\section{MATERIALS AND METHODS}

This study was conducted at Subang Lake, located in Petaling District, with a latitude of $3.1672^{\circ} \mathrm{N}$ and a longitude of $101.4798^{\circ} \mathrm{E}$ (Figure 1). Subang Lake is an endorheic lake and was built in 1950. The capacity of Subang Lake is about $777.00 \mathrm{mg}$. The impounding capacity of Subang Lake is $3531.8 \mathrm{~mL}$, and the impounding area is 96 hectares. The catchment area of Subang Lake is $10.16 \mathrm{~km}^{2}$, and the maximum depth is $8.5 \mathrm{~m}$. The study area was divided into seven sampling points which are Muka Sauk (SP1), Tanjung Panjang (SP2), Tanjung Batu 4 (SP3), Tanjung Jelutong (SP4), Tanjung Hantu (SP5), Tanjung Ampang (SP6), and Tanjung Terung (SP7) (Figure 2).

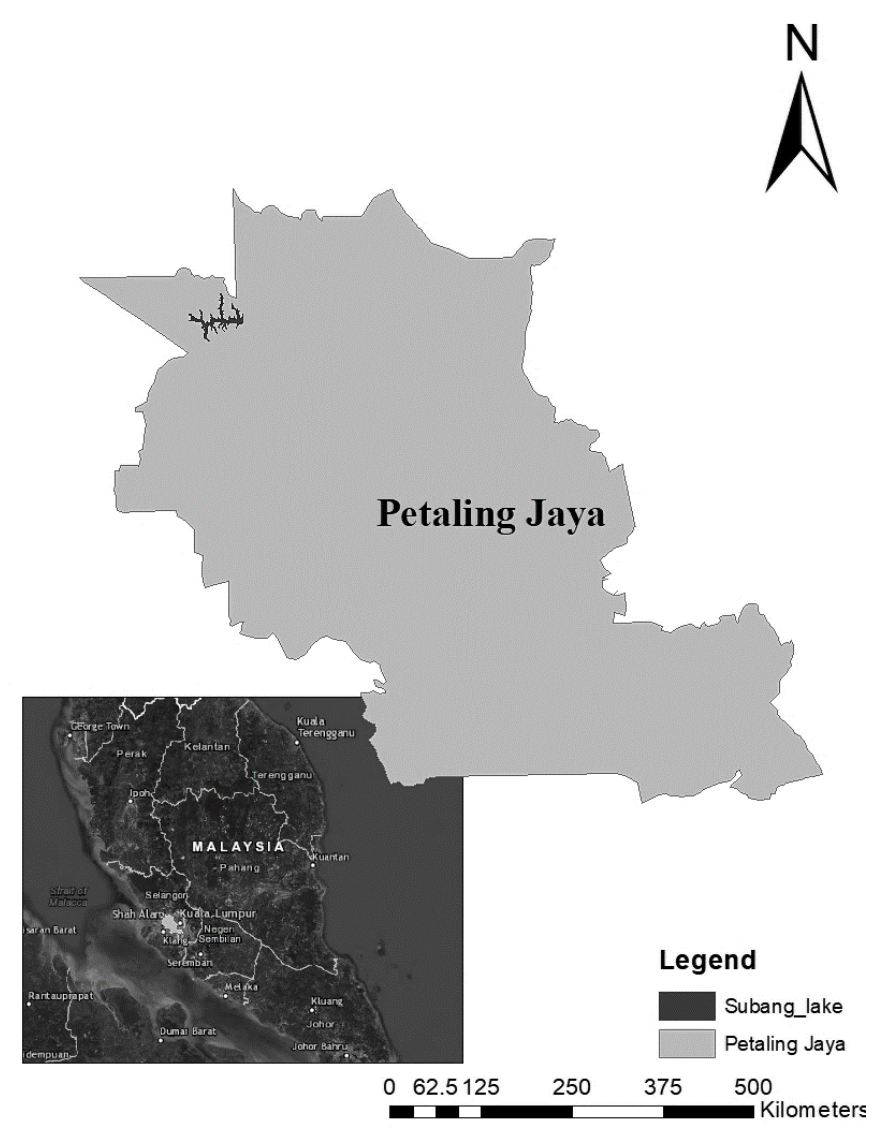

Figure 1. The location of Subang Lake in Selangor, Malaysia 
Xeai Li Chai, Rohasliney Hashim, Muhammad Nur Aiman Rahmat, Mohamad Hamizan Kamaludin,

Nur Ain Habullah and Izharuddin Shah KamaruddinUshada and David Yudianto

The sampling was carried out four months (July 2018, June 2019, August 2019, and October 2019) using five different mesh sizes of gill net (1 1/2 inch, 2 inches, 3 inches, 4 inches, and 5 inches) and two fish traps. The sampling locations were stratified-randomly selected with major coverage of Subang Lake. The gill nets and fish traps were set overnight in four consecutive days at each sampling point from morning $0800 \mathrm{~h}$ and checked every four hours until $1800 \mathrm{~h}$. The total length of individual fish was measured using the measuring board in centimeter, and the weight of individual fish was taken as the nearest gram using an electronic balance (LT2002, Smith).

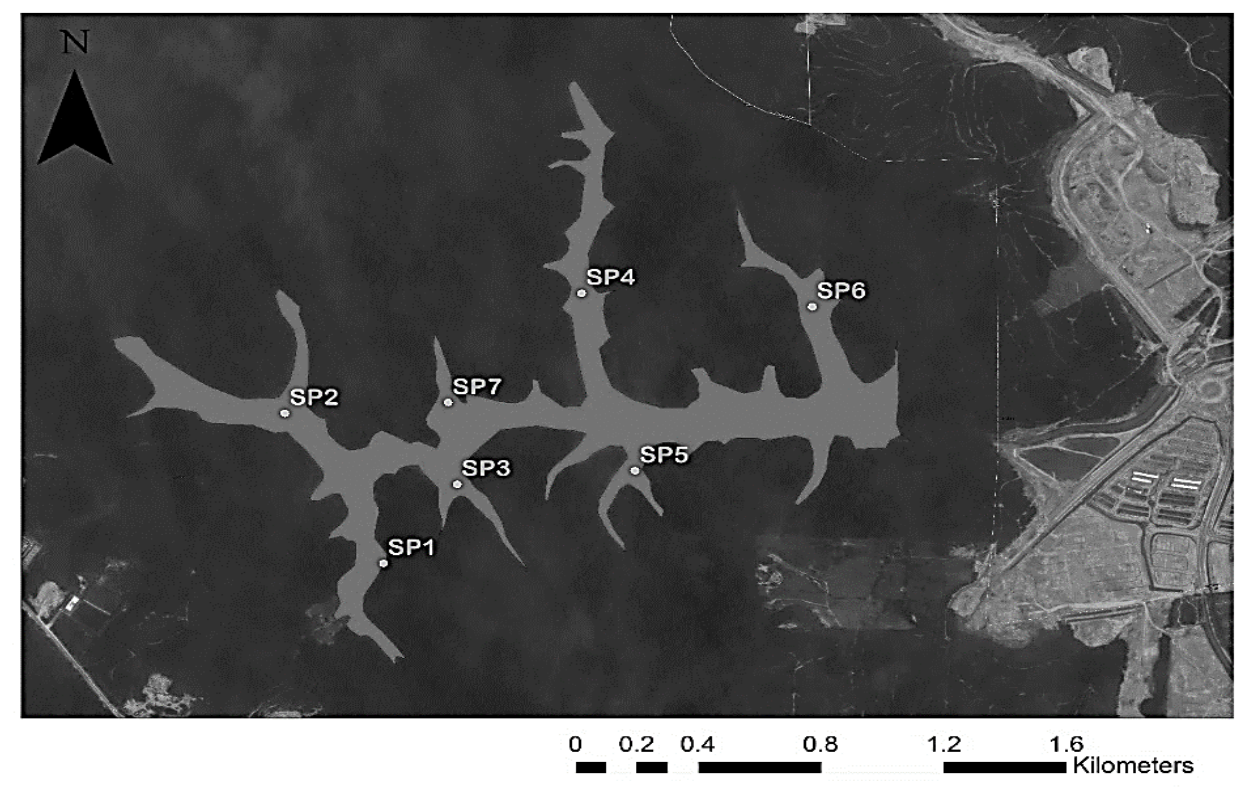

Figure 2. The distribution of seven sampling points in Subang Lake

The growth pattern of the fish can be determined by the score of the growth exponents, $b$. According to Froese (2006), the allometric growth versus isometric growth and the different body shapes of the individual species can be determined from the $82 \%$ of the variance in a plot of $\log a$ over $b$. In most fishes, the value of $b>3.0$ indicates a positive allometric growth where the relative body thickness or plumpness is increased with the length, whereas when the value of $b<3.0$ indicates negative allometric growth. The fish body growth is relatively less rotund as the length increases (Amonodin et al., 2018). The current form of LWR determines the length-weight relationship, and also, the linear regression analysis is used to determine the length-weight (log-transformed) relationship (Froese, 2006). The linear regression of LWR is $\log W=\log a+\mathrm{b} \log L$, whereas the modern form of LWR is defined as Equation 1. 


$$
\mathrm{W}=a \mathrm{~L}^{b}
$$

Where,

$\mathrm{W}=$ Body weight $(\mathrm{g})$

$\mathrm{L}=$ Total length $(\mathrm{cm})$

$a=$ coefficient

$b=$ exponent

The condition factor is also used to determine the fishes' condition in their habitat (Jones et al., 1999). The relative condition factor of fish is determined by using the observed weight and the estimated weight. The relative condition factor is suitable for value $b</$ $>3$. The relative condition factor $(\mathrm{K})$ is used to assess a specific environment's fitness for fish growth through the deviation of an organism from the sample's average weight (Jisr et al., 2018). According to Le Cren (1951), $\mathrm{K} \geq 1$ indicates the fish's growth condition is a good and contrary condition when $\mathrm{K}<1$. However, Barnham and Baxter (2003) stated that the $\mathrm{K}$ value greater than 1.4 is categorized as excellent fish growth, whereas less than 1.0 showed a poor growth pattern. The mean condition factor $(\mathrm{K})$ is defined as Equation 2.

$$
\mathrm{K}=\mathrm{W} / \mathrm{W}
$$

Where,

$\mathrm{W}=$ Observed weight of fish individual

$\mathrm{W}^{\prime}=$ Estimated weight of fish individual

Descriptive statistical analysis was conducted by calculating the mean values of the length-weight relationship and the relative condition factor of Beardless barb and Bronze featherback throughout the sampling periods because of these factors affecting the lengthweight relationship, such as habitat and seasonal effect. Stomach fullness, maturity stage, age, and sex were not considered (Hamid et al., 2015).

\section{RESULTS AND DISCUSSIONS}

A total of 422 individuals of Beardless barb and 344 individuals of Bronze featherback were captured in this study (Table 1). Both fish species were the dominant species in Subang Lake. The total length of Breadless barb at Subang Lake ranged from $10.0 \mathrm{~cm}$ to $16.9 \mathrm{~cm}$ with the mean total length of $13.11 \pm 1.31 \mathrm{~cm}$, and the weight ranged from 11.80 $\mathrm{g}$ to $70.52 \mathrm{~g}$ with the mean weight of $31.88 \pm 9.93 \mathrm{~g}$ (Table 1). The mean of the total length and weight of Bronze featherback is $16.05 \pm 2.07 \mathrm{~cm}$ and $30.38 \pm 15.63 \mathrm{~g}$ (Table 1). The total length of Bronze featherback ranged from $9.80 \mathrm{~cm}$ to $26.40 \mathrm{~cm}$, and the weight of Bronze featherback varied from $4.99 \mathrm{~g}$ to 153.04 (Table 1). The coefficient of determination $\left(\mathrm{r}^{2}\right)$ value of Beardless barb and Bronze featherback was 0.8588 and 0.8828 , respectively 
Xeai Li Chai, Rohasliney Hashim, Muhammad Nur Aiman Rahmat, Mohamad Hamizan Kamaludin,

Nur Ain Habullah and Izharuddin Shah KamaruddinUshada and David Yudianto

(Table 1). A lower value of $\mathrm{r}^{2}$ indicated a narrow range of fish size with higher correlation and statistical significance (Gaygusuz et al., 2012). The lower value of $\mathrm{r}^{2}$ also affected by human error during data collection and inconsideration of outliers of length and weight during the LWR calculation. Good quality of prediction of linear regression was obtained from the high coefficient of determination values.

The $b$ value of Beardless barb and Bronze featherback was 2.884 and 2.886, respectively, categorized as negative allometric growth (Table 1). The negative allometric growth was recorded for both fish species $(b<3)$ suggested that the fish species have a relatively slow growth rate. According to Froese (2006), the expected $b$ value was varied from $2.5-3.5$. The $b$ value that exceeded the range of standard $b$ value was considered a consequence of small sample sizes (Gaygusuz et al., 2012); however, the case did not happen in this study. The K value of Breadless barb (1.184) and Bronze featherback (1.010) indicated that the fish have a fair growth pattern (Barnham \& Baxter, 2003). The condition factor was associated with the LWR that was recorded in this study.

Table 1

Summary of length-weight relationship and relative condition factor. $K$ value was based on Barnham and Baxter (2003)

\begin{tabular}{|c|c|c|c|c|c|c|c|c|}
\hline Species & $\mathbf{N}$ & $\begin{array}{l}\text { Lmin- } \\
\max \\
(\mathrm{cm})\end{array}$ & $\begin{array}{l}\text { Wmin- } \\
\max (g)\end{array}$ & a & b & $\mathbf{r}^{2}$ & $\begin{array}{l}\text { Growth } \\
\text { behavior }\end{array}$ & $\mathbf{K}$ \\
\hline $\begin{array}{l}\text { Cyclocheilichthys } \\
\text { apogon } \\
\text { (Beardless barb) }\end{array}$ & 422 & $\begin{array}{l}10.0- \\
16.9\end{array}$ & $\begin{array}{l}11.80- \\
70.52\end{array}$ & 0.01843 & 2.884 & 0.8588 & $\begin{array}{l}\text { Negative } \\
\text { allometric }\end{array}$ & 1.184 \\
\hline $\begin{array}{l}\text { Notopterus } \\
\text { notopterus } \\
\text { (Bronze } \\
\text { featherback) }\end{array}$ & 344 & $\begin{array}{l}9.80- \\
26.40\end{array}$ & $\begin{array}{l}4.99- \\
153.04\end{array}$ & 0.0095 & 2.886 & 0.8828 & $\begin{array}{l}\text { Negative } \\
\text { allometric }\end{array}$ & 1.010 \\
\hline
\end{tabular}

The negative allometric growth of both fish species, Beardless barb and Bronze featherback, was recorded in the present study. This result is in accord to Nyanti et al. (2018) where a negative allometric growth of Beardless barb $(b=2.678)$ was recorded from downstream of the Batang Ai Dam (Malaysia); however, the condition factor of Beardless barb was in good condition $(K>1)$ (Table 2). Food availability and the environmental condition were the significant factors that affect the length-weight relationship and growth condition of fish in Batang Ai Dam. The findings of Rosli and Zain (2016), Zulkafli et al. (2016), Hamid et al. (2015), and Isa et al. (2010) indicated a positive allometric growth of Beardless barb in most of the Malaysian freshwater bodies (Table 2).

Several previous studies recorded that Bronze featherback has positive allometric growth $(b>3)$. For instance, the positive allometric growth of Bronze featherback was 
recorded at Pedu Lake (Kedah) and Sukhna Lake (India) with 3.25 (Isa et al., 2010) and 3.57, respectively (Kaur \& Rawal, 2017) (Table 2). According to Dubey et al. (2012), Bronze featherback has a positive allometric growth in the less disturbance or favorable condition in River Ken (India). Besides, negative allometric growth was reported in the finding of Khan (2003) due to several factors such as the selectivity of gill nets, relatively cold climate, and the lower productivity of Tilaiya Reservoir. Sarkar et al. (2013) documented that difference in parameter $b$ value was attributed to the differences in the specimens' observed length ranges. The positive allometric growth was recorded in the study by Kaur and Rawal (2017) due to the smaller range of length $(21.00-28.30 \mathrm{~cm})$; however, the length ranges of Bronze featherback $(\mathrm{N}=344)$ caught in Subang Lake were more comprehensive $(9.80 \mathrm{~cm}$ to $26.40 \mathrm{~cm})$.

The finding of Martin-Smith (1996) categorized the $b$ value range from $2.60-2.75$ as flattened body shape, whereas the $b$ value ranged from $2.88-3.15$ as a heavy-bodied. The expected range of exponent $b$ value was $2.5-3.5$. Although negative allometric growth was obtained in the current study, the results were within the expected range and considered heavy-bodied. According to Isa et al. (2010), a higher value of $b$ showed that the environment is more favorable for the fish species. Moreover, Rosli and Zain (2016) and Dalu et al. (2013) suggested the variation of $b$ value was due to the variation of length and weight, seasonal variation, gonad maturity, diet, health, food availability, and other environmental factors.

The relative condition factor $(\mathrm{K})$ in the present study for both fish species was greater than 1. According to Le Cren (1951), K > 1 reflects a healthier physiological state. However, Barnham and Baxter (2003) stated that the $\mathrm{K}$ value greater than 1.40 is categorized as good to excellent growth condition, whereas the $\mathrm{K}$ value lower than 1.0 categorized as poor growth condition. Barnham and Baxter (2003) have a comprehensive identification of fish conditions than Le Cren (1951). Hence, the condition of the Beardless barb and Bronze featherback were found to be relatively fair $(1<\mathrm{K}<1.40)$ at Subang Lake based on the standard of Barnham and Baxter (2003). This study found that both Beardless barb and Bronze featherback dominated Subang Lake. Therefore, both fishes condition indicated that Subang lake provides adequate food supply and favorable environmental conditions for them to survive and grow. According to Sharip et al. (2017), Subang Lake was a mesotrophic-eutrophic lake with the domination of green algae, which provides sufficient food for both fish species. Furthermore, seasonal variation, breeding activities, and biological activities indicated no physiological stress to these populations. With a distinctive slender and elongated body, giving Bronze featherback a knife-like appearance (Kumar \& Karin, 2016), it was evident that its body increases more in length than in weight. Thus, the body form and shape strongly affect the relative condition. Logically, the morphological factors also influence body form and weight, and, by extension, condition 
Xeai Li Chai, Rohasliney Hashim, Muhammad Nur Aiman Rahmat, Mohamad Hamizan Kamaludin,

Nur Ain Habullah and Izharuddin Shah KamaruddinUshada and David Yudianto

factor. It is possible for an individual fish could increase energetic fitness without a change in body weight.

Table 2

Literature reports pf allometric growth of fish compared to findings in the current study

\begin{tabular}{|c|c|c|c|c|c|c|c|}
\hline Species & $\begin{array}{l}\text { Study } \\
\text { area }\end{array}$ & $\mathbf{N}$ & b & $\begin{array}{l}\text { Location } \\
\text { (Literature) }\end{array}$ & $\mathbf{N}$ & b & References \\
\hline \multirow[t]{4}{*}{$\begin{array}{l}\text { Cyclocheilichthys } \\
\text { apogon } \\
\text { (Beardless barb) }\end{array}$} & $\begin{array}{l}\text { Subang } \\
\text { Lake }\end{array}$ & 422 & 2.884 & $\begin{array}{l}\text { Batang Ai } \\
\text { dam }\end{array}$ & 208 & 2.678 & $\begin{array}{l}\text { Nyanti et al. } \\
(2018)\end{array}$ \\
\hline & & & & $\begin{array}{l}\text { Muda } \\
\text { Reservoir }\end{array}$ & $\begin{array}{l}\text { Males: } \\
166 \\
\text { Females: } \\
141\end{array}$ & $\begin{array}{l}\text { Males: } \\
3.150 \\
\text { Females: } \\
3.185\end{array}$ & $\begin{array}{l}\text { Rosli and } \\
\text { Zain (2016) }\end{array}$ \\
\hline & & & & $\begin{array}{l}\text { Temengor } \\
\text { Reservoir }\end{array}$ & 233 & 3.157 & $\begin{array}{l}\text { Hamid et al. } \\
(2015)\end{array}$ \\
\hline & & & & $\begin{array}{l}\text { Kerian } \\
\text { River basin }\end{array}$ & 46 & 3.516 & $\begin{array}{l}\text { Isa et al. } \\
(2010)\end{array}$ \\
\hline \multirow{4}{*}{$\begin{array}{l}\text { Notopterus } \\
\text { notopterus } \\
\text { (Bronze } \\
\text { featherback) }\end{array}$} & $\begin{array}{l}\text { Subang } \\
\text { Lake }\end{array}$ & 344 & 2.886 & $\begin{array}{l}\text { Sukhna } \\
\text { Lake }\end{array}$ & 45 & 3.570 & $\begin{array}{l}\text { Kaur and } \\
\text { Rawal (2017) }\end{array}$ \\
\hline & & & & River Ken & 28 & 3.32 & $\begin{array}{l}\text { Dubey et al. } \\
(2012)\end{array}$ \\
\hline & & & & Pedu Lake & 120 & 3.250 & $\begin{array}{l}\text { Isa et al. } \\
(2010)\end{array}$ \\
\hline & & & & $\begin{array}{l}\text { Tilaiya } \\
\text { Reservoir }\end{array}$ & 300 & 2.902 & Khan (2003) \\
\hline
\end{tabular}

$* \mathrm{~N}=$ number of individuals, $b=$ exponent $b($ slope of the equation $\log W=\log a+b \log L)$

\section{CONCLUSION}

In conclusion, both fish species are in a healthy intermediate state (fair condition growth) when the K value is greater than 1.4. Subang lake's ecological factors are observed to support these dominant fishes. The negative allometric growth of both fish species may be attributed to the fish's morphological characteristics. The results of the length-weight relationship (LWR) and relative condition factor $(\mathrm{Kn})$ recorded in this study contribute to the knowledge of the fish condition in Subang Lake and the relevant information in the conservation management of Subang Laker's fish. The results obtained can also provide useful information about the fish communities in an endorheic lake. 


\section{ACKNOWLEDGMENT}

The authors wish to thank funding from Geran Putra Universiti Putra Malaysia (UPM) (GP/2017/9564500) for completing the study. Also, high appreciation to Mohd Sulkifly Ibrahim, Abdul Rahman Sokran@ Mohamad, and Dalina Jaafar for their help and assistance for this study in 2018. Apart from that, high gratitude for Pengurusan Air Selangor Sdn. Bhd. and Lembaga Urusan Air Selangor for their approval for the authors to carry out their study smoothly in Subang Lake. Finally, thank you for the kindest cooperation given by the supervisor of Subang Lake, Mohd Rezza Haizad Abdullah, and all the staff (Rajuddin Hamid, Yusof Rohman, and Muhammad Fadzil Idris).

\section{REFERENCES}

Amonodin, M. R., Fadzil, N. F. M., Azmai, A. M. N., \& Hashim, R. (2018). A review of length-weight relationships of freshwater fishes in Malaysia. Transylvanian Review of Systematical and Ecological Research, 20(1), 55-68. https://doi.org/10.1515/trser-2018-0005

Barnham, C. P. S. M., \& Baxter, A. (2003). Condition factor, K, for salmonid sh. State of Victoria, Department of Primary Industries.

Dalu, T., Nhiwatiwa, T., \& Clegg, B. (2013). Length-weight relationships and condition factors of six fish species caught using gill nets in a tropical African reservoir, Zimbabwe. Transactions of the Royal Society of South Africa, 68(1), 75-79. https://doi.org/10.1080/0035919X.2012.733318

Dubey, V. K., Sarkar, U. K., Kumar, R. S., Mir, J. I., Pandey, A., \& Lakra, W. S. (2012). Length-weight relationships (LWRs) of 12 Indian freshwater fish species from an un-impacted tropical river of Central India (River Ken). Journal of Applied Ichthyology, 28(5), 854-856. https://doi.org/10.1111/j.14390426.2012.02005.x

Farooq, N., Qamar, N., Rashid, S., \& Panhwar, S. K. (2017). Length-weight relationship of eleven species of marine catfishes from the northern Arabian Sea coast of Pakistan. Chinese Journal of Oceanology and Limnology, 35(5), 1218-1220.

Froese, R. (2006). Cube law, condition factor and weight-length relationships: History, meta-analysis and recommendations. Journal of Applied Ichthyology, 22(4), 241-253. https://doi.org/10.1111/j.14390426.2006.00805.x

Gaygusuz, Ö., Aydin, H., Emiroğlu, Ö., Top, N., Dorak, Z., Gaygusuz, Ç. G., Baskurt, S., \& Tarkan, A. S. (2012). Length-weight relationships of freshwater fishes from the western part of Anatolia, Turkey. Journal of Applied Ichthyology, 29(1), 285-287. https://doi.org/10.1111/jai.12015

Hamid, M. A., Mansor, M., \& Nor, S. A. M. (2015). Length-weight relationship and condition factor of fish populations in Temengor Reservoir: Indication of environmental health. Sains Malaysiana, 44(1), 61-66. https://doi.org/10.17576/jsm-2015-4401-09

Isa, M. M., Rawi, C. S., Rosla, R., Shah, S. A. M., \& Shah, A. S. R. M. (2010). Length - weight relationships of freshwater fish species in Kerian River Basin and Pedu Lake. Research Journal of Fisheries and Hydrobiology, 5(1), 1-8. 
Xeai Li Chai, Rohasliney Hashim, Muhammad Nur Aiman Rahmat, Mohamad Hamizan Kamaludin,

Nur Ain Habullah and Izharuddin Shah KamaruddinUshada and David Yudianto

Jisr, N., Younes, G., Sukhn, C., \& El-Dakdouki, M. H. (2018). Length-weight relationships and relative condition factor of fish inhabiting the marine area of the Eastern Mediterranean city, Tripoli-Lebanon. The Egyptian Journal of Aquatic Research, 44(4), 299-305

Jones, R. E., Petrell, R. J., \& Pauly, D. (1999). Using modified length-weight relationships to assess the condition of fish. Aquacultural engineering, 20(4), 261-276.

Karna, S. K., Sahoo, D., Panda, S., Vihar, V., Bhaban, M., \& Nagar, S. (2012). Length weight relationship (LWR), growth estimation and length at maturity of Etroplus suratensis in Chilika Lagoon, Orissa, India. International Journal of Environmental Sciences, 2(3), 1257-1267.

Kaur, V., \& Rawal, Y. K. (2017). Length-weight relationship ( LWR ) in Notopterus notopterus (Pallas) from Sukhna Lake, Chandigarh. IOSR Journal of Pharmacy and Biological Sciences, 12(4), 63-65. https:// doi.org/10.9790/3008-1204046365

Khan, M. A. (2003). Length-weight relationship and relative condition index of Notopterus notopterus (Pallas) of Tilaiya Reservoir, Bihar. Records of The Zoological Survey of India, 101, 233-239.

Kumar, K. H., \& Kiran, B. R. (2016). Relative condition factor of feather back, Notopterus Notopterus (Pallas) from Jannapura Pond, Bhadravathi Taluk, Karnataka. International Journal of Scientific Research in Science, Engineering and Technology, 2(1), 36-39.

Le Cren, E. D. (1951). The length-weight relationship and seasonal cycle in gonad weight and condition in the perch (Perca fluviatilis). The Journal of Animal Ecology, 20(2), 201-219. https://doi.org/10.2307/1540

Martin-Smith, K. M. (1996). Length/weight relationships of fishes in a diverse tropical freshwater community, Sabah, Malaysia. Journal of Fish Biology, 49(4), 731-734. https://doi.org/10.1006/jfbi.1996.0201

Nyanti, L., Soo, C., Ling, T., Sim, S., Grinang, J., Ganyai, T., \& Lee, K. (2018). Physicochemical parameters and fish assemblages in the downstream river of a tropical hydroelectric dam subjected to diurnal changes in flow. Hindawi International Journal of Ecology, 2018, 1-9.

Pope K. L. (2007) Condition. In C. S. Guy \& M. L. Brown (Eds.), Analysis and interpretation of freshwater fisheries data (pp. 423-471). American Fisheries Society.

Rosli, N. A. M., \& Zain, K. M. (2016). Preliminary assessment on autecological studies of beardless barb, Cyclocheilichthys apogon (valenciennes, 1842) from Muda Reservoir of Kedah, Malaysia. Tropical life sciences research, 27(supp1), 63-69. https://doi.org/10.21315/tlsr2016.27.3.9

Sarkar, U. K., Khan, G. E., Dabas, A., Pathak, A. K., Mir, J. I., Rebello, S. C., Pal, A., \& Singh, S. P. (2013). Length weight relationship and condition factor of selected freshwater fish species found in River Ganga, Gomti and Rapti, India. Journal of Environmental Biology, 34, 951-956.

Sharip, Z., Yusoff, F. M., \& Ismail, W. R. (2017). Trophic state characterisation for Malaysian lake. In M. Maghfiroh, A. Dianto, T. Jasalesmana, I. Melati, O. Samir, \& R. Kurniawan (Eds.), The 16th World Lake Conference (pp. 442-447). Research Center for Limnology, Indonesian Institute of Sciences.

Zulkafli, A. R., Amal, M. N. A., Shohaimi, S., Mustafa, A., Ghani, A. H., Ayub, S., Hashim, S., Anuar, M. I., \& Hasfairi, M. P. (2016). Length-weight relationships of 13 fish species from Pahang River, Temerloh District, Pahang, Malaysia. Journal of Applied Ichthyology, 32(1), 165-166. https://doi.org/10.1111/ jai.12959 